UDC 331.109:316.344.27

DOI: $10.15673 /$ fie.v12i1.1672

\author{
Kozak K. \\ Ph.D., Associate Professor \\ Department of Management and Logistics \\ E-mail: kozakkate.coach@gmail.com \\ ORCID ID: 0000-0002-8099-6607 \\ Sedikova I. \\ Doctor of Economics, Professor \\ Department of Management and Logistics \\ E-mail: irina-sedikova@ukr.net \\ ORCID ID: 0000-0003-4376-1267
}

Klevets M.

The student of the fourth grade of Management, Marketing and Logistics Faculty

Odessa National Academy of Food Technologies

Kanatna str., 112 Odesa, Ukraine, 65039

E-mail: maryaklevets@gmail.com

ORCID ID: 0000-0003-0259-4538

\title{
PECULIARITIES OF STAFF POLICY IN THE CONDITIONS OF INNOVATIVE CHANGES
}

At the present stage, the development of personnel policy of state organizations depends on the potential of public servants, the effectiveness of its use, innovative proposals and, in general, the state's innovation policy. The article substantiates the need to apply innovations in the practice of personnel management. The essence of the concept of "personnel innovation" has been revealed, the factors of innovation potential have been determined. Priority innovative approaches to the implementation of certain functions of personnel management in the state structure in the current conditions have beenanalysed. The relevance of the research into the issues of personnel policy formation can be justified by the need to improve its implementation in the conditions of innovative economy, globalization processes and development of digital economy. The success of an enterprise innovation policy is determined by two main factors: the ability of the enterprise to clearly identify what employee behaviour is required to achieve its strategy and the ability to use effective innovative management levers to direct employees to the desired behaviour. Both tasks are equally important and complex, especially in the face of the digital revolution.

Key words: personnel management, personnel policy, human resource, innovative methods, personnel potential, public administration.

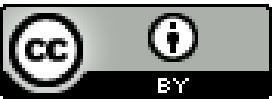

This work is licensed under a Creative Commons Attribution 4.0 International License http://creativecommons.org/licenses/by/4.0/
Statement of the problem and its connection with important scientific and practical tasks. To date, public personnel policy has a number of problems, which are mainly due to a lack of understanding of the needs of staff (including qualified professional staff), as well as to the inefficient use of human resources.

The following criteria become important: insufficient level of training of personnel in the field of strategic management, resistance to strategic changes and innovations, lack of financial resources, imperfection of the personnel motivation system, degradation of the role of personnel in the enterprise, imperfection of the legislative framework for personnel management, lack of flexibility and organizational flexibility methods of personnel management, insufficient information support for strategic personnel management and the problem of corporation culture of the civil service. However, now the state is losing its attractiveness as an employer in the labour market, as young professionals entering the civil service for further career advancement are forced to leave their jobs because of low pay. The salary of the civil service personnel is rather low, and additional social guarantees cannot sufficiently compensate for the significance and complexity of their activities, so attracting new personnel is a difficult process. However, it should be borne in mind that the increase in cash retention for non-upgraded staff cannot significantly improve labour efficiency [1].

The analysis of the latest publications on the problem. The peculiarities of introducing innovative approaches to state human resources policy are currently an under-researched issue among Ukrainian researchers. Among those who started research in this area are: O. V. Olshanskaya, A. O. Melnyk, T. E. Voronkova S. A. Kartashov, I. V. Bizyukova and others. Among the foreign researchers who also make a significant contribution to the coverage of this issue there is Graham Martin and Susan Hetrick, who characterized the principles of formation of human resourcesin their work "Strategic approach to human resource management".

However, in most scientific papers, only the element regarding the evaluation of the characteristics of managerial staff in particular and the issue of managerial training has been discussed. Therefore, there is an objective need to investigate this issue, which in general reveals the problem of formation of human resources in the Ukrainian market. 
Forming of the aims of the research. The purpose of the work is to optimize, rationalize and improve the workforce of civil servants through the use of innovative approaches to improve the personnel management system and personnel policy in public authorities as a whole.

Giving an account of the main results and their substantiation. Innovation is a universally recognized determinant of growth, which is a challenge for both scientists and professionals to understand how and why firms are innovating [2].

Personnel innovation is the end result of an innovation that leads to a change in personnel work as an object of management and to obtaining an economic, social or other kind of effect [3].

Important tools for the state's ability to coordinate and pursue innovation are all that are inherent in people in the workplace: human capital, a particular set of skills, knowledge, alternative ideas, opportunities, and more. Human capital studies have traditionally focused on education and training. The problem of motivational aspects of human capital, such as job satisfaction, organizational commitment, and willingness to change in the workplace (all of which have been shown to stimulate innovation), often goes unnoticed or is not given due importance in economic research today. The first feature of human capital to focus on is job satisfaction, defined as people's well-being or level of satisfaction with their work.

Job satisfaction supports a number of important functions for the firm, including knowledge pooling and problem-solving strategies [4]. People who are very satisfied with their job are more likely to be motivated, for example, they are motivated to make extra efforts, take risks, learn new skills, and promote unique ideas for their organization [5]. In contrast, people who are less satisfied with their work (for example, because they find their work hard) are less likely to respond to the motivation needed for successful innovation [6].

The second element of human capital to focus on is the identification of employees and management: their organization and the direction of synergistic results for their organization. Constructions such as organizational integration and dedication are especially important for understanding innovation, as innovative behaviour is often risky; these risks are more easily taken by people who trust and care about the success of their organization [7].

Finally, the third element of human capital that is worthy of attention is the willingness to change. A number of studies examine the role of employee readiness for change (for example, changing the level of technology, skills, and responsibilities required to improve the work performed) in determining organizational success and employee orientation toward innovations. The desire to change influences the acceptance or rejection of innovations [8].

It is important to note that the low level of innovation activity of state organizations is caused by the unacceptable financial costs for the development and implementation of innovations. However, in addition to financial factors, it is necessary to take into account such global factors that require increasing the innovativeness of the economy, such as the growth of internationalization, globalization of markets, the level of technological competition, changes in consumer values, etc. (table 1).

Table 1

Factors influencing the innovation potential of the enterprise [9]

\begin{tabular}{|l|l|}
\hline Evaluation criteria & \multicolumn{1}{|c|}{ Name of indicators of innovative potential of the enterprise } \\
\hline \multirow{4}{*}{$\begin{array}{c}\text { Scientific and } \\
\text { technical potential }\end{array}$} & $\begin{array}{l}\text { Avesence of organizational structure for innovation development and implementation } \\
\text { lectual property objects implemented which brought economic impact }\end{array}$ \\
\cline { 2 - 3 } & The level of competitiveness of innovative products (services) \\
\cline { 2 - 3 } & Market share of innovative products (services) \\
\cline { 2 - 3 } & $\begin{array}{l}\text { Existence of partnerships and personal relations with research institutes, enterprises, for- } \\
\text { eign partners }\end{array}$ \\
\hline \multirow{5}{*}{ Financing innovation potential } & Scientific level of employees, their degree and knowledge \\
\cline { 2 - 3 } & Availability of personnel with special education and experience in conducting GDRs \\
\cline { 2 - 3 } & The fluidity of scientific personnel \\
\cline { 2 - 3 } & Wage level \\
\cline { 2 - 3 } Infrastructure for & Condition of the retraining system \\
\cline { 2 - 3 } innovation & Composition of sources and forms of innovation financing \\
\cline { 2 - 3 } & The share of R\&D expenses in the cost \\
\cline { 2 - 3 } & Availability of own resources to finance innovation \\
\cline { 2 - 3 } & Level of financial risks \\
\cline { 2 - 3 } & $\begin{array}{l}\text { Presence of specialized laboratories, experimental base, devices, installations, etc. } \\
\text { pipelines, transport communications, etc. }\end{array}$ \\
\cline { 2 - 3 } & Access to the necessary resources (land, water, minerals, energy sources, etc.) \\
\cline { 2 - 3 } & Availability of a sales network that promotes innovative products to the markets \\
\cline { 2 - 3 } & The presence of companies and firms providing services of a special nature \\
\hline
\end{tabular}


The employee motivation plays a fundamental role in every organization that sets strategic goals for high performance. The direct relationship between the amount of employee motivation and workplace performance can be emphasized. That is, managers find it a very important task to identify motivational factors that more incentivize employees to qualitatively work while performing their daily work activity.

And since the main productive resource that provides the current activity and development of the enterprise is its labour collective (personnel), it is advisable to consider the personnel management strategy as the central functional strategy. In this regard, a number of professionals point out an important distinguishing feature of HR strategy: it is closely linked to all other functional strategies of the organization, and HR is a way by which all business strategies of the organization are achieved.

In Ukraine, only financial and economic incentives are often used (only the material needs of employees are taken into account), and such as labour or professional are not used at all. Unlike foreign personnel policy, where motivation theory has not only been studied for decades and deepened, but also put into practice. There are enough theories and concepts that each country uses to achieve the best results. Overseas experience can serve as a base for developing new, innovative ways and tools to motivate staff [10].

Therefore, analysing the realities of the current state of human resources situation, it should be noted that human resources technologies must meet the following requirements:

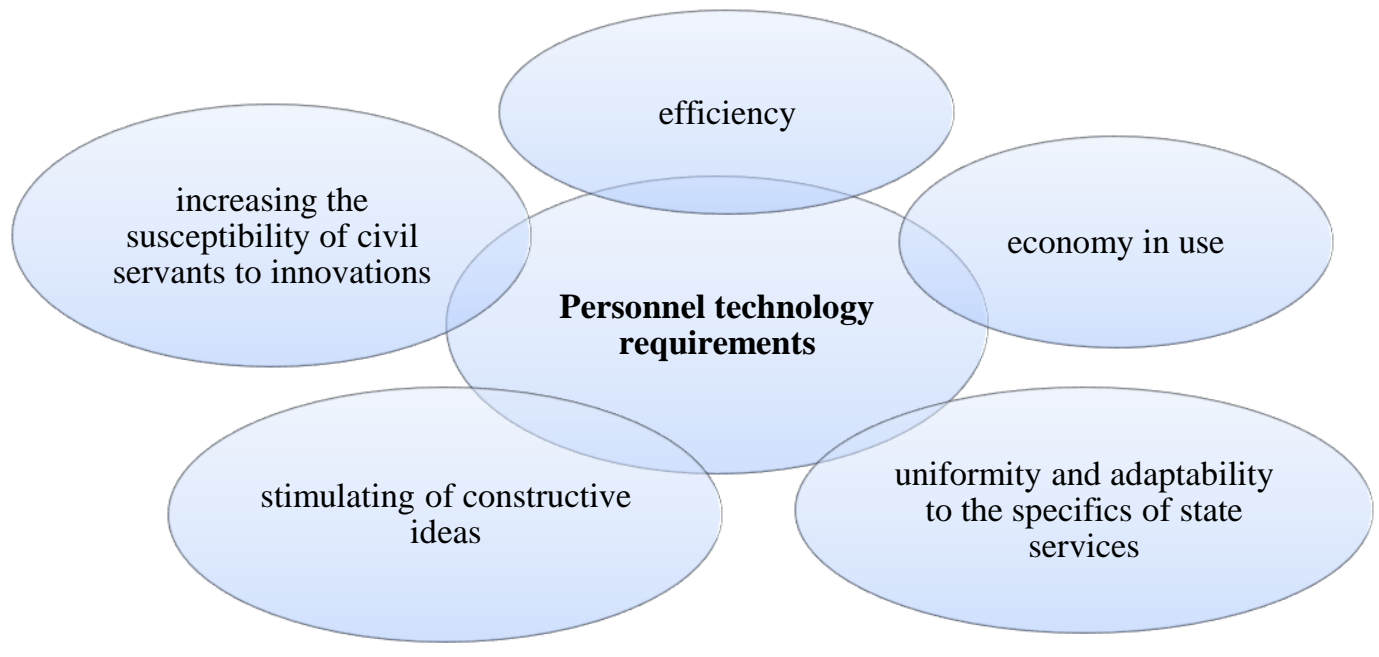

Fig.1. Criteria for personnel technologies of public administration*

*developed by the author based on [10]

The essence of personnel innovation is ultimately the introduction of an innovation that will change personnel work as an object of management and obtain a socio-economic or other effect. Thus, following a personnel innovation, one can expect an effect of growth.

These criteria can be met by innovative human resources technologies that represent the latest or upgraded ways of interacting with human resources.

The most obvious and initial innovation is the management approach according to which human resources and personnel management is considered as human resources management, which takes place at larger levels: regional, national, international.

If you apply this approach to the civil service, there are several aspects of their application:

- it is not necessary to strictly adhere to the contract, but to achieve more than it foresees; the activity;

- civil servants' initiative is an integral part of

- increasing the speed of decision making;
- remuneration is paid in accordance with the performance;

- getting rid of division of labour, working in teams;

- conflicts within the team are resolved by providing a supportive environment and a high level of culture.

The Law of Ukraine on Civil Service defines the principles, legal and organizational methods of ensuring public, professional, politically impartial, effective, citizen-oriented civil service, which functions in the interests of the state and society, as well as the procedure for realisation by citizens of Ukraine of the right of equal access to public service, which based on their personal qualities and achievements [12].

According to the above law, the National Agency of Ukraine for Civil Service (NACS) provides vocational training through a system of educational institutions, institutions and organizations, regardless of ownership, which have the right to provide relevant educational services. 
Components of personnel management systems [11]

\begin{tabular}{|c|c|c|c|c|}
\hline \multicolumn{5}{|c|}{ Components of personnel management systems } \\
\hline $\begin{array}{l}\text { The process } \\
\text { of hiring } \\
\text { employees }\end{array}$ & $\begin{array}{c}\text { Staff } \\
\text { development }\end{array}$ & $\begin{array}{c}\text { Employees' } \\
\text { individual aims }\end{array}$ & $\begin{array}{c}\text { Evaluation } \\
\text { of employees }\end{array}$ & $\begin{array}{c}\text { Staff } \\
\text { motivation }\end{array}$ \\
\hline \multicolumn{5}{|c|}{ Control parameters } \\
\hline $\begin{array}{l}\text { Hiring employees } \\
\text { with creative think- } \\
\text { ing and experience } \\
\text { in participating in } \\
\text { innovative projects }\end{array}$ & $\begin{array}{l}\text { Promotion and rota- } \\
\text { tion to managerial } \\
\text { positions of employ- } \\
\text { ees with different } \\
\text { basic education }\end{array}$ & $\begin{array}{l}\text { Providing an oppor- } \\
\text { tunity to spend part } \\
\text { of the working time } \\
\text { on realisation of } \\
\text { own ideas to benefit } \\
\text { of an enterprise }\end{array}$ & $\begin{array}{l}\text { Concentration of } \\
\text { your attention on the } \\
\text { work results or on } \\
\text { the employees }\end{array}$ & $\begin{array}{l}\text { The prospect of } \\
\text { broadening of the } \\
\text { professional activity, } \\
\text { the principle of an } \\
\text { individual approach } \\
\text { to the career- } \\
\text { qualification stimu- } \\
\text { lation }\end{array}$ \\
\hline \multicolumn{5}{|c|}{ Result } \\
\hline $\begin{array}{l}\text { Growth of innova- } \\
\text { tive staff innovation }\end{array}$ & $\begin{array}{c}\text { Raise of balance of } \\
\text { staff management } \\
\text { system }\end{array}$ & $\begin{array}{l}\text { Involvement in en- } \\
\text { trepreneurial activ- } \\
\text { ity, a faster response } \\
\text { to new possibilities }\end{array}$ & $\begin{array}{l}\text { Raise of employees } \\
\text { concentration on } \\
\text { strategies of enter- } \\
\text { prise development }\end{array}$ & $\begin{array}{l}\text { Raise of employees' } \\
\text { working enthusiasm }\end{array}$ \\
\hline
\end{tabular}

We can see the types of vocational training in Fig.2.

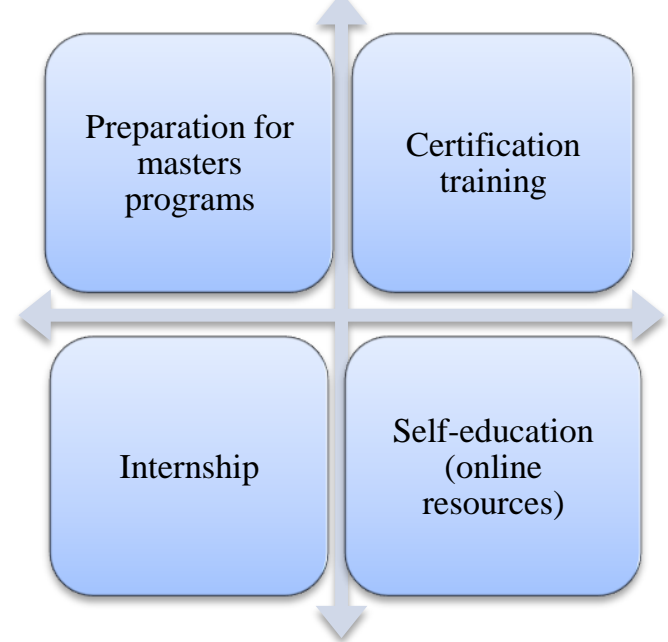

Fig.2. Types of vocational training *

*developed by the author based on [12]

Vocational training is acquisition and improvement of professional knowledge, skills and abilities of civil servants, heads of local state administrations, their first deputies and deputies, officials of local selfgovernment, which provides an adequate level of their professional qualification for their professional activity [13].

For example, the following online platforms offer self-education:

- Prometheus https://prometheus.org.ua (Ukrainian platform of mass open online courses that allows you to view free training courses);

- VUM online, Open University of Maidan https://vumonline.ua/ (More than 30 topics are presented for free training on the platform);
- EdEra (Education Era) https://www.edera.com/ (Ukrainian educational project aimed at making education in Ukraine high quality, accessible and available in a global educational context);

- Coursera https://ru.coursera.org (An American educational project founded by Sanford University professors. The portal offers free online courses from leading US universities in various fields: government and society, information technology, personal development, language learning, etc.);

-EdX https://www.edx.org (an online platform for mass open interactive courses founded by the Massachusetts Institute of Technology and Harvard University, where you can listen to such interactive courses). 
The order according to which the 2020 training plan is set, according to which there are a total number of persons who are required to undergo training. Let's look at Table 3,consider the name of the professional development program and the number of people in the first half of 2020

Table 3

Schedule of training of civil servants and officials of local self-government for 2020 *

\begin{tabular}{|c|c|c|c|c|}
\hline № & $\begin{array}{l}\text { Name of the ad- } \\
\text { vanced training pro- } \\
\text { gram }\end{array}$ & $\begin{array}{l}\text { Number } \\
\text { of hours }\end{array}$ & Category of listeners & $\begin{array}{l}\text { Number } \\
\text { of persons }\end{array}$ \\
\hline \multicolumn{5}{|c|}{ Short term programs } \\
\hline \multicolumn{5}{|c|}{ January } \\
\hline 1. & $\begin{array}{l}\text { Preventing of corrup- } \\
\text { tion in public admini- } \\
\text { stration }\end{array}$ & 6 & $\begin{array}{c}\text { Public servants of 4-9 remuneration groups of Darnytsya } \\
\text { district state administration in Kyiv }\end{array}$ & 30 \\
\hline \multicolumn{5}{|c|}{ February } \\
\hline 2. & $\begin{array}{l}\text { Organization of re- } \\
\text { cord keeping in pub- } \\
\text { lic authorities }\end{array}$ & 6 & $\begin{array}{c}\text { Civil servants of 4-9 pay groups of the Pechersk District } \\
\text { State Administration in Kyiv }\end{array}$ & 20 \\
\hline \multicolumn{5}{|c|}{ March } \\
\hline 3. & $\begin{array}{l}\text { Industrial cooperation } \\
\text { within the framework } \\
\text { of the Ukraine - } \\
\text { European Union dia- } \\
\text { logue }\end{array}$ & 10 & Public servants of 4-9 pay groups & 25 \\
\hline \multicolumn{5}{|c|}{ April } \\
\hline 4. & $\begin{array}{l}\text { Development of } \\
\text { stress resistance. Ex- } \\
\text { press methods of } \\
\text { stress management }\end{array}$ & 6 & $\begin{array}{l}\text { Civil servants of } 4-8 \text { pay groups of the Department of } \\
\text { Construction and Housing of the executive body of Kyiv } \\
\text { City Council (Kyiv City State Administration) }\end{array}$ & 15 \\
\hline \multicolumn{5}{|c|}{ May } \\
\hline 5. & $\begin{array}{l}\text { Conflicts, stresses, } \\
\text { management manipu- } \\
\text { lation }\end{array}$ & 6 & $\begin{array}{l}\text { Civil servants of 5-8 pay groups of the Depart- } \\
\text { ment of Housing and Communal Infrastructure } \\
\text { of the Executive Body of Kyiv City Council } \\
\text { (Kyiv City State Administration) }\end{array}$ & 15 \\
\hline \multicolumn{5}{|c|}{ June } \\
\hline 6. & $\begin{array}{l}\text { Professional burnout } \\
\text { in public service }\end{array}$ & 6 & $\begin{array}{l}\text { Civil servants of 4-9 remuneration groups of the Des- } \\
\text { niansky District State Administration in Kyiv }\end{array}$ & 30 \\
\hline
\end{tabular}

*Developed by the author based on [14]

A total of 135 workers are required to undergo advanced training in the six months of 2020 under the selective programs of Decree No. 12 of 09/01/2020. This will undoubtedly have a positive impact on the formation of personnel policy in local self-government bodies and the state structure as a whole.

In order to ensure the proper conditions for the realization of the right of civil servants, heads of local state administrations, their first deputies, officials of local self-government for professional development, the NACS created the Ukrainian School of Government (USG) on February 21, 2019 [15].

The Ukrainian School of Government is an institution of postgraduate education that belongs to the sphere of management of the National Agency of Ukraine for Civil Service. The main programs of the USG advanced training effectively improve personnel policy in public authorities and are described in table 4.

Table 4

Programs of the USG Training Centre of advanced training *

\begin{tabular}{|c|l|}
\hline № & \multicolumn{1}{|c|}{ Advanced training programs } \\
\hline 1 & Prevention and detection of corruption \\
\hline 2 & Topical issues related to the implementation of the civil service legislation \\
\hline 3 & Professional program for professionals for reforms \\
\hline 4 & Training of civil servants of CEB and other bodies, whose positions belong to 6-9 pay groups \\
\hline 5 & Training of civil servants and local self-government officials in personnel management \\
\hline 6 & Innovative technologies of personnel management \\
\hline
\end{tabular}


Continue of table 4

\begin{tabular}{|c|l|}
\hline$№$ & \multicolumn{1}{c|}{ Advanced training programs } \\
\hline 7 & Leadership and technology management personnel \\
\hline 8 & Organization of activity of heads of district state administrations in the conditions of reforms \\
\hline 9 & Psychology of effective activity \\
\hline 10 & Time management \\
\hline 11 & Management of personnel in the state body \\
\hline 12 & Formation of teamwork skills in public service \\
\hline 13 & Access to public information \\
\hline
\end{tabular}

Conclusions and prospects of the further investigations. The provisions on practical application and specifics of the introduction of personnel technologies, innovative methods and tools for staff motivation in Ukraine require further study and refinement. For example, particular attention should be paid to defining the content and correctness of the use of the term "personnel management", which is identified with the term "personnel policy". Thus, Denysenko M. P., Budyakova O. Y. define "personnel management" as an activity aimed at achieving the most efficient use of human capital to solve complex issues at the enterprise and personal goals. Contemporary understanding of the concept of efficiency is increasingly becoming more meaningful, not only in economic terms - as economy, productivity, profitability, profitability, quality, innovation [16]. And as Yuriy Kovbasyuk noted, "personnel policy" is a deliberate strategic activity related to the planning and forecasting of formation, professional development and rational use of personnel, defining the goals and priorities of personnel activity [17].
It can be said that personnel management is a personnel policy in practice. Assessment of the quality of personnel policy in the system of social and labour relations of the civil service can ensure the creation of a situation when the employee's position should determine the possibilities of his self-realization, as well as taking into account his individual features, needs, values. The latter can help to create optimal conditions for the prospects of employment in the public service. The prospect of further research is to develop a specific approach and techniques for comprehensive assessment of quality of work in the public service, based on foreign experience.

Therefore, the issues of the peculiarities of personnel policy in the context of innovative changes require further study, thus, personnel technologies are a necessary way of quantitative and qualitative characterization of civil servants, since many social and economic problems of Ukraine can be solved by improving the quality of public service. Innovative human resources technologies need to be implemented and applied to the public civil service, as their use will greatly enhance the efficiency of personnel work in the authorities.

\section{References}

1. Olshanska, O. V., Melnyk, A. O., \& Voronkova, T. Ye. (2018). Suchasni problemy ekonomichnoho rozvytku Ukraiiny. Kyiv: TOV «DKS tsentr».

2. Montalvo, C. (2006). What triggers change and innovation. Technovation, 26(3), 312-323. doi: 10.1016/j.technovation.2004.09.003

3. Horelov, D. V., Danylyna, O. I., \& Malikova, Ya. I. (2015). Innovatsionnyiy menedzhment v upravlenii personalom. Moscow: «Dashkov i K".

4. Judge T.A., \& Kammeyer-Mueller J.D. (2012). Rev. Annu. Job attitudes. Psychol., 341-367. doi: 10.1146/annurev-psych-120710-100511

5. Whitman, D. S., Van Rooy, D. L., \& Viswesvaran, C. (2010). Satisfaction, citizenship behaviours, and performance in work units: a meta-analysis of collective construct relations. Pers. Psychol, (63 (1), 41-81. doi: 10.1111/j.1744-6570.2009.01162.x

6. Eatough, E. M., Chang, C., Milosovic, S. A., Johnson, R. E., \& Appl, J. (2011). Relationship of role stressors with organizational citizenship behavior: a meta analysis. Psychol., (96), 619-632. doi: 10.1037/a0021887

7. Dalal, R. S., \& Appl, J. (2005). A meta-analysis of the relationship between organizational citizenship behavior and counterproductive work behavior'. Psychol., (90), 1241-1255. doi: 10.1037/0021-9010.90.6.1241

8. Pulakos, E. D., Arad, S., Donovan, M. A., Plamondon, K. E., \& Appl, J. (2000). Adaptability in the workplace: development of a taxonomy of adaptive performance. Psychol., (85), 612-624. doi: 10.1037/00219010.85.4.612

9. Kadrova polityka innovatsiino-oriientovanoi orhanizatsii. Retrieved January 24, 2020, from https://stud.com.ua/66337/menedzhment/kadrova_politika_innovatsiyno_oriyentovanoyi_organizatsiyi 
10. Aktualni problemy upravlinnia personalom ta ekonomiky pratsi. (2012). Zb. Materialiv IV Vseukr. Nauk.Prakt. Konf. Stud., Aspirantiv, Molodykh Uchenykh, 01-335.

11. Leli, Yu. H. (2016). Innovatsiyini pidkhody do upravlinnia personalom pidpryiemstva v suchasnykh umovakh (abst. kand. ekon. nauk: 08.00.04.), Zaporizhzhia: Klasych. pryvat. un-t., 01-20.

12. Pro derzhavnu sluzhbu: Zakon Ukrainy vid 19 veresnia 2019 roku № 117-IX za stanom na 14 sichnia 2020 r. (2020). Retrieved January 19, 2020, from http://search.ligazakon.ua/l_doc2.nsf/link1/T150889.html

13. NADS: Profesiine navchannia. (2020). Retrieved January 19, 2020, from

https://nads.gov.ua/diyalnist/profesijne-navchannya

14. Pro pidvyshchennia kvalifikatsii derzhavnykh sluzhbovtsiv, posadovykh osib mistsevoho samovriaduvannia u 2020 r. (2020). Rozporiadzhennia №12 Vid 09.01.2020, 01-05. doi: 10.1055/a-1091-2819

15. Kontseptsiia rozvytku ukrainskoi shkoly uriaduvannia. (2019). Retrieved January 19, 2020, from https://usg.org.ua/concept-ukra-nsku-shkolu-uryadu/

16. Ekonomika innovatsiinoi diialnosti pidpryiemstv. Suchasni osoblyvosti upravlinnia personalom pidpryiemstv. (2019). Retrieved January 25, 2020, from https://webcache.googleusercontent.com/search?q=cache:Y2WOripzI4UJ:https://er.knutd.edu.ua/bitstream/123456789/ 14205/1/NRMSE2019_V3_P109-110.pdf \&cd=1\&hl=ru\&ct=clnk\&gl=gr

17. Kovbasiuk, Yu. V. (2012). Derzhavna kadrova polityka v Ukraini: stan, problemy ta perspektyvy rozvytku (pp. 01-03). Kyiv: NADU.

Received 25 January2020

Approved 8 February 2020 Available in Internet 31.03 .20

Козак Е.Б.

кандидат экономических наук, доцент кафедра менеджмента и логистики E-mail: kozakkate.coach@gmail.com ORCID ID: 0000-0002-8099-6607

\section{Седикова И.А.}

доктор экономических наук, профессор кафедра менеджмента и логистики

E-mail: irina-sedikova@ukr.net

ORCID ID: 0000-0003-4376-1267

Клевец М.В.

студентка 4 курса фракультета менеджмента, маркетинга и логистики Одесская национальная академия пищевых технологий ул. Канатная, 112, г. Одесса, Украина, 65039

E-mail: maryaklevets@gmail.com

ORCID ID: 0000-0003-0259-4538

\section{ОСОБЕННОСТИ КАДРОВОЙ ПОЛИТИКИ В УСЛОВИЯХ ИННОВАЦИОННЫХ ИЗМЕНЕНИЙ}

На современном этапе развитие кадровой политики государственных организаций зависит от потенциала государственных служащих, эффективности его использования, инновационных предложений и в целом инновационной политики государства. В статье обоснована необходимость применения инноваций в практике управления персоналом. Раскрыта сущность понятия «кадровая инновация», определены фракторы инновационного потенциала. Осуществлен анализ приоритетных инновационных подходов к осуществлению отдельных функций управления персоналом в структуре в современных условиях. Актуальность исследования вопросов формирования кадровой политики можно обосновать необходимостью совершенствования ее реализации в условиях инновационной экономики, процессов глобализации и развития цифровой экономики. Успех инновационной кадровой политики предприятий определяется двумя основными факторами: способностью предприятия четко определить, какое поведение работников требуется для достижения его стратегии и возможностью применять эффективные инновационные управленческие рычаги для направления работников на желаемое поведение. Обе задачи равнозначно важны и сложно сформированы, особенно в условиях цифровой революции.

Один из основных факторов экономического роста в современных условиях развития Украины - это адаптивная, гибкая, мобильная кадровая политика и инновационные процессы, помогающие при формировании её концепции. Поэтому, актуальность исследования вопросов формирования кадровой политики выявлена необходимостью совершенствования ее реализации в условиях инновацион - 
ной экономики и процессов глобализации. Выяснение содержания категорий «кадровая политика», «управление персоналом» обусловило поиск стратегических решений и механизма ее реализации на различных уровнях власти. Необходимо раскрыть особенности современной кадровой политики на уровне государства, региона и предприятия, а также провести классификацию сочетания и комплекса макро-, мезо- и микроэкономических факторов, которые определяют кадровую политику.

Поливариантность подходов и решений выдвинутой проблематики подтверждает необходимость исследований в данной области для поиска новых эвристических и эмпирических аспектов формирования и стратегии развития кадровой политики социально-экономических систем в государстве. Перспективой дальнейшего исследования является разработка особого подхода и методик комплексной оценки качества труда на государственной службе опираясь на зарубежный опыт.

Поэтому, особенности кадровой политики в условиях инновационных изменений требуют дальнейшего изучения, исходя из этого: разработка методов управления системой формирования государственной кадровой политики остается по прежнему актуальной проблемой для отечественной экономики.

Ключевые слова: управление персоналом, кадровая политика, человеческий ресурс, инновационные методы, кадровый потенциал, государственное управление.

Козак К.Б.

кандидат економічних наук, доцент кафедра менеджменту та логістики E-mail: kozakkate.coach@gmail.com ORCID ID: 0000-0002-8099-6607
Седікова I.O.

доктор економічних наук, професор кафедра менеджменту та логістики

E-mail: irina-sedikova@ukr.net

ORCID ID: 0000-0003-4376-1267

Клевець М.В.

студентка 4 курсу факультету менеджменту, маркетингу та логістики

Одеська національна академія харчових технологій

вул. Канатна 112, м. Одеса, Україна, 65039

E-mail: maryaklevets@gmail.com

ORCID ID: 0000-0003-0259-4538

\section{ОСОБЛИВОСТІ КАДРОВОЇ ПОЛІТИКИ В УМОВАХ ІННОВАЦІЙНИХ ЗМІН}

На сучасному етапі розвиток кадрової політики державних організацій залежить від потенціалу державних службовців, ефективності його використання, інноваційних пропозицій і в цілому інноваційної політики держави. У статті обґрунтовано необхідність застосування інновацій в практиці управління персоналом. Розкрито сутність поняття «кадрова інновація», визначено чинники інноваційного потенціалу. Здійснено аналіз пріоритетних інноваційних підходів до здійснення окремих функцій управління персоналом в структурі в сучасних умовах.

Актуальність дослідження питань формування кадрової політики можна обґрунтувати необхідністю вдосконалення її реалізації в умовах інноваційної економіки, процесів глобалізації та розвитку цифрової економіки. Успіх інноваційної кадрової політики підприємств визначається двома основними факторами: здатністю підприємства чітко визначити, яка поведінка працівників потрібна для досягнення його стратегії і можливістю застосовувати ефективні інноваційні управлінські важелі для спрямування працівників на бажану поведінку. Обидва завдання рівнозначно важливі і складно сформовані, особливо в умовах цифрової революції.

Один з основних фракторів економічного зростання в сучасних умовах розвитку України - це адаптивна, гнучка, мобільна кадрова політика та інноваційні процеси, що допомагають при формуванні їі концепції. Тому, актуальність дослідження питань формування кадрової політики виявлена необхідністю вдосконалення ії̈ реалізації в умовах інноваційної економіки і процесів глобалізації. 3'ясування змісту категорій «кадрова політика», «управління персоналом» зумовило пошук стратегічних рішень і механізму її реалізації на різних рівнях влади. Необхідно розкрити особливості сучасної кадрової політики на рівні держави, регіону та підприємства, а також провести класифікацію поєднання і комплексу макро-, мезо- і мікроекономічних чинників, які визначають кадрову політику.

Поліваріантність підходів і рішень висунутої проблематики підтверджує необхідність досліджень в даній області для пошуку нових евристичних і емпіричних аспектів формування та стратегії розвитку кадрової політики соціально-економічних систем в державі. Перспективою подальшого дослідження є розробка особливого підходу і методик комплексної оцінки якості праці на державній службі спираючись на зарубіжний досвід. 
Тому, особливості кадрової політики в умовах інноваційних змін вимагають подальшого вивчення, виходячи з цього: розробка методів управління системою фрормування державної кадрової політики залишається як і раніше актуальною проблемою для вітчизняної економіки.

Ключові слова: управління персоналом, кадрова політика, людський ресурс, інноваційні методи, кадровий потенціал, державне управління.

\section{Література}

1. О.В. Ольшанська, А.О. Мельник, Т.С. Воронкова. Сучасні проблеми економічного розвитку України: монографія. Київ: ТОВ «ДКС центр», 2018. 184 с. doi: 10.1016/j.technovation.2004.09.003

2. Montalvo C. What triggers change and innovation // Technovation, 26 (3), 2006. P. 312-323

3. Горелов Д. В., Данилина О. І., Малікова Я. І. Инновационный менеджмент в управлении персоналом: учебные издания. Москва: «Дашков и К", 2015. 11 с.

4. Judge T.A., Kammeyer-Mueller J.D., Rev. Annu. Job attitudes // Psychol., 2012. P. 341-367. doi: 10.1146/annurev-psych-120710-100511

5. Whitman D.S., Van Rooy D.L., Viswesvaran C. Satisfaction, citizenship behaviours, and performance in work units: a meta-analysis of collective construct relations // Pers. Psychol, 63 (1), 2010. P. 41-81. doi: 10.1111/j.1744-6570.2009.01162.x

6. Eatough E.M., Chang C., Milosovic S.A., Johnson R.E., Appl J. Relationship of role stressors with organizational citizenship behavior: a meta analysis // Psychol., 96, 2011. P. 619-632. doi: 10.1037/a0021887

7. Dalal R.S., Appl J. A meta-analysis of the relationship between organizational citizenship behavior and counterproductive work behavior' // Psychol., 90, 2005. P. 1241-1255. doi: 10.1037/0021-9010.90.6.1241

8. Pulakos E.D., Arad S., Donovan M.A., Plamondon K.E.. Appl J. Adaptability in the workplace: development of a taxonomy of adaptive performance // Psychol., 85, 2000. P. 612-624. doi: 10.1037/00219010.85.4.612

9. Кадрова політика інноваційно-орієнтованої організації: URL:https://stud.com.ua/66337/menedzhment/kadrova_politika_innovatsiyno_oriyentovanoyi_organizatsiyi (дата звернення: 24.01.2020).

10. Актуальні проблеми управління персоналом та економіки праці: зб. матеріалів IV Bceукр. наук.практ. конф. студ., аспірантів, молодих учених: Житомир, 12 квіт. 2012 р. Житомир : ЖДТУ, 2012.335 с.

11. Лелі Ю.Г. Інноваціийні підходи до управління персоналом підприємства в сучасних умовах : автореф. дис. ... канд. екон. наук: 08.00.04. Запоріжжя: Класич. приват. ун-т., 2016. 20 с.

12. Про державну службу: Закон України від 19 вересня 2019 року № 117-IX за станом на 14 січня 2020 p. / Кабінет Міністрів України. URL: http://search.ligazakon.ua/__doc2.nsf/link1/T150889.html (дата звернення: 19.01.2020)

13. НАДС: Професійне навчання: [Веб-сайт]. Київ. URL: https://nads.gov.ua/diyalnist/profesijnenavchannya (дата звернення: 19.01.2020).

14. Про підвищення кваліфікації державних службовців, посадових осіб місцевого самоврядування у 2020 р: Розпорядження №12 від 09.01.2020 // Київська міська державна адміністрація. Київ: Виконавчий орган Київської міської ради, 2020. 1-5 с. doi: 10.1055/a-1091-2819

15. Концепція розвитку української школи урядування: [Веб-сайт]. Київ, $2019 . \quad$ URL: https://usg.org.ua/concept-ukra-nsku-shkolu-uryadu/ (дата звернення: 19.01.2020).

16. Економіка інноваційної діяльності підприємств. Сучасні особливості управління персоналом підприємств: веб-сайт. Київ, 2019. https://webcache.googleusercontent.com/search?q=cache:Y2WOripzI4UJ:https://er.knutd.edu.ua/bitstream/123456789/ 14205/1/NRMSE2019_V3_P109-110.pdf+\&cd=1\&hl=ru\&ct=clnk\&gl=gr (дата звернення: 25.01.2020).

17. Державна кадрова політика в Україні: стан, проблеми та перспективи розвитку: наукова доповідь / Ковбасюк Ю. В. та ін. Київ: НАДУ, 2012. 3 с.

Стаття надійшла 25.01.2020

Стаття прийнята до друку 8.02.2020

Доступно в мережі Internet 31.03.2020

Цитування згідно ДСТУ 8302:2015

Kozak K., Sedikova I., Klevets M. Peculiarities of staff policy in the conditions of innovative changes // Food Industry Economics. 2020. Vol.12, Issue 1. P. 86-94. doi: 10.15673/fie.v12i1.1672

Cite as APA style citation

Kozak, K., Sedikova, I., \& Klevets, M. (2020). Peculiarities of staff policy in the conditions of innovative changes. Food Industry Economics, 12(1), 86-94. doi: 10.15673/fie.v12i1.1672 